\title{
Analysis on the Affinities between Nathaniel Hawthorn and Pearl in The Scarlet Letter
}

\author{
Yueming Wang ${ }^{1}$ \\ ${ }^{1}$ Department of Foreign Language Teaching, Inner Mongolia University for the Nationalities, Tongliao, China \\ Correspondence: Yueming Wang, Department of Foreign Language Teaching, Inner Mongolia University for the \\ Nationalities, Tongliao, China. Tel: 86-139-475-9023. E-mail: ymwang1969@163.com
}

Received: June 23, 2014 Accepted: October 9, 2014 Online Published: November 25, 2014

doi:10.5539/ells.v4n4p57 URL: http://dx.doi.org/10.5539/ells.v4n4p57

\begin{abstract}
Nathaniel Hawthorne's The Scarlet Letter has been rated as his best work among his many works by critics. Hawthorne focuses on the evolvement of Pearl's character in detail, reflecting his own psyche through the image of Pearl in the novel. Hawthorne portrays Pearl using his own family background. They share the origin affinity because both of their descendants are degenerative. They share the character affinity because both of them are solitary and rebellious. Hawthorne makes a picture of Pearl from his family background. Both of them share inner-thought affinity because they long for freedom and independence. Hawthorne also depicts Pearl from his religious background. They share attitude affinity because both of them are contradictory towards religion. They share symbolism affinity because Hawthorne employs ambiguity to show Pearl's ambiguity.
\end{abstract}

Keywords: affinities, social background, family background, religious background

\section{Introduction}

The Scarlet Letter is one of the most excellent literary works written by American, Romanticism novelist Nathaniel Hawthorne in the $19^{\text {th }}$ century. When talking about this novel, a comment is often quoted from D. H. Lawrence, "No other book is so deep, so dual, so complete (Male, 1957)." Critics sort the criticism about this novel into neat categories, such as the feminist approach, biographical approach, historical approach, or other approaches to help readers understand its connotation.

Duyckinck (1850) clarified that The Scarlet Letter was a psychological romance that studies the character in which the human heart is anatomized. According to Baym (1976), Hester Prynne presents her bravery; Dimmesdale reveals his timidity; Chillingworth shows his malice; and Pearl, as an embodiment of Hester's sin, is a kind of variant (Edwin Percy Whipple, 1988). All these characters represent their own understanding of life, with the materials being fused completely in the writer's mind.

The biographical approach sees the novel mainly as a reflection of Hawthorne's life. Critics of this approach have found details and facts about Hawthorne and try to prove their connection to the story. The critics regard the novel as an index to the fascinating psyche of the author. Byam's Nathaniel Hawthorne and His Mother (Byam, 1976) illustrates how Hawthorne turned the facts of his mother's life into the fictive experience of Hester Prynne. Hester Prynne, the heroine in the novel, like Hawthorne's mother, was socially stigmatized to bear and rear her child alone.

Some critics believe Hawthorne's daughter, Una, is the original shape of Pearl, but much evidence shows that Hawthorne, himself, is the origin of Pearl. Hawthorne's family background, social background, and religious background bear witness to the affinities between Pearl and Hawthorne. Throughout the story, the affinities between Hawthorne and Pearl are striking.

\section{Affinity with the Same Family Background}

\subsection{The Origin Affinity between Hawthorne and Pearl: Degeneration}

Hawthorne's origin was different from that of his contemporaries. Emerson, Longfellow, Lowell, and Holmes were all born into a social class which, at their time, was dominant in New England. Hawthorne came from a family eminent in early colonial days, but long lapsed into obscurity which the modern word would call degenerate (Wendell, 1900). He was said to be often troubled by the idea that the decrease of his family's fortune 
was due to the sin of his ancestors.

Hawthorne was, by his ancestors' sin, worthless and disgraced. One of Hawthorne's ancestors was Judge Hathorne of the Salem Witch Trials. He presided over the notorious Salem Witchcraft Trail in 1692 and was cursed by the husband of one of the convicted witches. This case was muddy for Hathorne's descendants. At the age of 21, after Nathaniel Hawthorne's graduation from college and feeling guilty about his ancestor's deed, he added the " $\mathrm{w}$ " to his surname. According to The Concise Dictionary of American Literary Biography - Colonization to American Renaissance, 1640-1865, both in England and America, the family name could be spelled both with and without a "w." Hawthorne used this "w" as a token of signaling the degeneration of his ancestors.

In The Scarlet Letter, Pearl, like Hawthorne, was born into disgrace. Because of the mistake of her mother's misconduct, this little girl became a living crimson "A" when she was born. She appears at the start of the novel with Hester Prynne being stared at by thousands of eyes on the scaffold. After being released from the prison, Hester lived a secluded life regarding Pearl as a token of her adultery.

The biographical critics prove The Scarlet Letter to be a mirror of the author's life. Nathaniel Hawthorne was not "a legitimate child" of the revenue system, who was born nobly. More like Pearl, he was the illegitimate child with the unaffiliated, unmarried mother, cut out of the cloth that was scarlet in hue. It is said that Hawthorne's father, a sea captain, had died of yellow fever in Dutch Guiana when he was only four years old. In the novel, "Who is Pearl's father?" is echoed from the beginning. Pearl is an illegitimate child, too. Both of them had no father. Given the precariousness of both their pasts, the onus for both Pearl and Hawthorne must be the same in order to go forth into the world.

When the news of Hawthorne's father's death came, the Hawthorne family moved in with the Manning family in Salem. Hawthorne's mother withdrew to her upstairs bedroom, coming out only rarely during the remaining forty years of her life. Pearl's mother, Hester Prynne, after being set free from the prison, lived a solitarily life on the outskirts of town. Both mothers lived in almost complete isolation. Nathaniel Hawthorne and Pearl were brought up in the same state.

\subsection{Character Affinities between Hawthorne and Pearl: Solitude and Rebellion}

Both of them had unhappy and disgraced childhoods. There are similarities between Pearl and Hawthorne's characters worth noticing.

Based on the biographical approach, Hawthorne, lived a solitary life. He ordered his servant to take the food outside the door; he drew the curtain at daytime; he disliked parties; if he could not refuse an invitation, he preferred sitting alone and not talking. A foot injury caused lameness and kept Hawthorne from school for 14 months in November 1813. During that time little Hawthorne hunted, fished, and ran wild. In July 1819, he returned to Salem to live with his mother's family, under the guardianship of his uncle, Robert Manning. He was rebellious and refused to obey his mother and uncle's strong desire to become a sailor. He became a writer, and his imaginative literature in this novel showed his rebellious spirit of freedom and individuality towards the traditional idea of New England.

Pearl, like Hawthorne, lived a solitary life, too. When walking with her mother on the street, the little girl saw those little puritans' special feelings toward those who were peculiar to the local people. They abused, cursed, and showed contempt for Hester and Pearl. When hearing the words and seeing the behaviors which were discriminatory, Pearl realized the insurmountable circle around her at her age of seven. If someone talked to her, Pearl would keep silent. She just glanced at them, but never wanted to be acquainted with them. She never created friends in her play world because she had no friends. Pearl loved her mother, but at the same time, she was rebellious to her mother's will. Neither smiles nor frowns possessed any calculable influence for Pearl. Hester was ultimately compelled to stand aside and permit the child to be swayed by her own impulses. Just as Hawthorne was rebellious, so, too, was Pearl.

\section{Affinity with the Same Social Background}

\subsection{Inner-Thought Affinities between Hawthorne and Pearl: Freedom and Independence}

When Hawthorne graduated from Bowdoin College, his full harvest was the accomplishment of thoughts. He read a lot and become acquainted with the local history: Gothic buildings, old women's stories, the bloody house, and other local attractions. He knew everything native. In Hawthorne's time, the American dream of independence and freedom had actually been put into practice. As a true and native artist who had been to foreign countries only in his late fifties, he had a deep love and thought for America. Hawthorne, who lived nearly fifty years in his native country, hoped to express what the Yankee life meant and the deep characteristics 
of the surrounding New England life. As James, Jr. (1988) said, “The thing (of The Scarlet Letter) was absolutely American; it belongs to the soil, to the air; it came out of the very heart of New England."

Hawthorne described the little girl as someone who feared nothing and longed for freedom and independence; she was the only person who held out hope for tomorrow. At the very beginning of the novel, the literary flavor was sad and somber. However, just beside the door of the prison was a bunch of wild roses that were fragrant and charming. The wild roses here virtually refer to Pearl. She brightens Hester's gray life and relieves the stiff atmosphere of the novel. Pearl's laughter gives her mother encouragement for life, and she also brings energy to the darkness. Hawthorne succeeded in creating a character embodying the authentic American dream of freedom and independence (Carpenter, 1988). Pearl's name, her attire, and her behavior sums up her individuality. The individuality Pearl shows proved that she doesn't fear anything of the old world. She is typically native to the new world that has been starved of individuality. "Fear nothing" is a kind of American native spirit; it encourages American people to seek freedom and independence (Chang, 1998).

In Chapter 7, the children of the Puritans had nothing interesting to play with, so they insulate Hester and Pearl for amusement. "Behold, verily, there is the woman of the scarlet letter, and of the truth, moreover, there is the likeness of the scarlet letter running along by her side! Come, therefore, let us fling mud at them!" Hearing these, Pearl stamped her foot, shook her hands, made a rush at her enemies, put them all to fight, and showed her fear of nothing. In chapter 10, little Pearl and Hester pass along the footpath that traversed the enclosure, Pearl skipped irreverently from one grave to another, and she began to dance upon it. Pearl disliked restraint and the obsolete, she melted with the wild, sported herself into the water, made a boat with birch bark, caught the besieged little marine organisms, and quickened her paces to run after the sea birds. Behind her vigorous energy and inflexible limbs, she longed for freedom. This freedom and independence, reflecting Hawthorne's thoughts, were typically native to this new world that had been lacking individualities. Pearl's independence and freedom embodied Hawthorne's "American Dream." Though Hester embodies the Authentic dream of a new life in the wilderness of the new world and of self-reliant action to realize the ideal, but her dream of freedom is impossible for Hester's sin is certain (Carpenter, 1944).

\section{Affinity with the Same Religious Background}

\subsection{Attitude Affinity between Hawthorne and Pearl: Contradiction}

Rubinstein (1988) regards Hawthorne as "an extremely paradoxical figure." He had a deep-rooted interest in religion, towards which, however, his attitude was contradictory. He seems "suspicious of all doctrines or sects, he thought of himself as a Christian, but never went to church (Donohue, 1985)."

On one side, he attacked the obsessively religious action and attitude of the Puritans, blaming them for the violence and crimes that they committed of discriminating and persecuting those who held different views. But on the other side, he used the fundamental religious criteria to judge good from evil.

Hawthorne's contradictory attitude to religion was from his ancestor's misdeed, who was a very stern Puritan. Some of his ancestors were men of prominence in the Puritan theocracy of $17^{\text {th }}$ century New England. One of them, Nathaniel Hawthorne's great-great grand father, William Hathorne was a colonial magistrate known for his role in persecution of the Quakers. According to Brooks \& Lewis (1973), William Hathorne once whipped a disciple, Anne Coleman, to be bound to the tail of a cart and given ten stripes in Salem, ten in Boston, and ten in Dedham, and then driven off into the forest. The cruel punishment of pagans reminds us of the time when the Puritans first landed in this new world. Individual and separate wickedness followed: murder, theft, alcoholism, and incest and whoring were brought there. In order to fight against the evil, authorities borrowed many brutalities of the English justices such as cutting off ears, bearing holes in women's tongues with red-hot irons, and starving prisoners (Miller, 1991). During that time, corporal punishment was quite a common phenomenon. This same ancestor once ordered to remove a burglar's ear and brand him on the forehead with a letter B. In fact, such letters were surely worn in New England. Baym (1976) states, "Instances have been recorded of a D for drunkard, and an I, signifying incest." Hawthorne realized the evil at the core of humanity and the darkness of life; he did not flatter his ancestor's misdeed. He expressed his sympathy to the persecuted in his novel. He inherited heavy guilt and took serious consideration of the responsibility he should take for his ancestors.

In some sense, Hawthorne was a typical product restricted by the Puritanism social culture. He had the Puritan intuitive knowledge and circumspect. To him, all kinds of social problems such as various kinds of conflicts between men and all types of crimes arose from one single root, that is, the inherent evilness in the Puritan world. Hawthorne kept that "Evil, as well as good impulses, were native to every human heart and must be combated afresh by every man and woman in every generation (Rubinstein 1988)." 
Coupled with Hawthorne's critical spirit, he also took pride in his ancestors. He noted this in "The Custom House," in the introductory part of The Scarlet Letter. Hathorne ancestry had never been disgraced by a single unworthy member. His pride also came from his grandfather who was a hero in the Revolutionary War. Hawthorne's writing about Pearl reflected his paradoxical understanding of Puritanism. Thus, the device of ambiguity is used to symbolize Pearl's aspects of evil and purity.

Perhaps the most efficient way to prove Pearl's purity and evilness is to read Hawthorne, the Artist written by Leland Schubert. Schubert (1958) first made reference to the specific people who thought of Pearl as evil. All through the book, Pearl's life is symbolic. She symbolizes her mother's sin. No matter where the mother went, the little girl accompanied her. Pearl reminds her mother of the sin as the plot continues. Miller (1991) thought Pearl was amoral because Pearl was too young to judge good from evil. Garllitz (1988) strongly believed that Pearl "is not the innocent result of lust." Chang (1993), in his book, supported this point of view, "Pearl is repeatedly associated with the devil, with sin, and with witchcraft." Some critics discuss Pearl's indifference. Hunt (1967) is one of the few dissenters for Pearl's indifference. In his essay The Scarlet Letter: Hawthorne's Theory of Moral Sentiment, he argues that Pearl was more or less indifferent to the feelings of others. He meant Pearl has a lack of sympathy.

\subsection{Symbolism Affinity between Hawthorne and Pearl: Ambiguity}

Nathaniel Hawthorne's contradictory attitude toward religion made him portray Pearl both as an evil girl and a pure girl. As a master of symbolism, Hawthorne also created great ambiguity by employing strong symbols to reflect his own psyche. For example, the forest in the novel symbolizes in various ways. It is a symbol of the world of darkness and evilness; it is where Pearl could run wild and play freely to seek her freedom and independence; it is also a symbol of the natural world governed by natural laws as opposed to the artificial, strict community with its man-made Puritan law. For Hawthorne, objects and matters seem less important than the idea they represented.

Symbolism is a literary device to be made use of to portray another individual or object. We cannot say it stands for or represents a meaning, but it really evokes, suggests, or manifests something. Pearl's symbol of treasure of youth is evident. Her name designated her to be a child of great value and worth. A pearl in the ocean is found and extracted after careful labor. Pearl was brought into the world at a great cost. Hester named her Pearl, as being of a great price, purchased with all she had. She was brought into the world at the expense of her mother's public condemnation.

Nathaniel Hawthorne's ambiguity with symbolism of Pearl is clear to most of readers. Hawthorne used this writing technique to reflect his mind and gave the readers a chance to judge their own opinion of the affinity between Pearl and him. some feminist criticisms believe that Hawthorne's ambiguity is 'an attempt' to work out his ambiguity towards himself.

\section{Conclusion}

Throughout The Scarlet Letter, one particular question leads the action. It is a question on everyone's lips, spoken or not, from beginning to the end. It is a question being asked both by readers and different characters in the novel when Hester stepped onto the scaffold in the public square: Whose child was Pearl? Like many great tragedies, The Scarlet Letter deals with the quest for truth, the revelation of the secret. The quest for truth is an effort to know Pearl. Knowing the truth of Pearl is understanding Nathaniel Hawthorne's mind, they had affinities between each other, the image of Pearl is the reflection of Nathaniel Hawthorne' psyche.

Like all literary masterpieces, The Scarlet Letter continuously stimulates criticisms, and steadier and maybe more progressively constructive stream of studies would be added to his stature in American literature. The analysis of the affinities of family background, social background, and religious background between Pearl and Hawthorne help the readers understand the novel from a new aspect.

\section{Acknowledgments}

I would like to express my gratitude to my foreign friend, Emily Minter, who spent her precious time correcting my manuscript. I also want to show my appreciation to Mrs. An Guiqin at the Inner Mongolian University for the Nationalities who gave me instructive comments on this thesis.

\section{References}

Baym, N. (1976). The Major Phase I, 1850: The Scarlet Letter. Cornell: Cornell University Press.

Brooks, C., \& Lewis, R. W. B. et al. (Ed.). (1973). American Literature: The Makers and the Making. New York: St. Martin's Press. 
Carpenter, F. I. (1988). Scarlet A Minus. In S. Gross et al. (Eds.), The Scarlet Letter: An Authoritative Text essays in Criticism and Scholarship. New York: W. W. Norton \& Company.

Chang, Y. (Ed.). (1993). Selected Readings in American Literary Criticism. Tian Jin: Nan Kai University Press.

Donohue, C. (1985). The New England Source of The Scarlet Letter. In S. Bradley et al. (Eds.), The Scarlet Letter: AN Authoritative Text Backgrounds and Sources Criticism. New York: W.W.Norton and Company.

Duyckinck, E. A. (1956). The Scarlet Letter: A Psychological Romance. In B. Harding (Ed.), Nathaniel Hawthorne, Critical Assessment. Bodwin: MPG Books Ltd.

Garllitz, B. (1988). Pearl. New York: W. W. Norton \& Company.

Hawthorne, N. (1992). The Scarlet Letter. Wordsworth Edition Limited.

Hunter, L. (1967). The Scarlet Letter: Hawthorne's Theory of Moral Sentiment. Oxfrod University Press.

James Jr., H. (1978). Densely Dark, with a Spot of Vivid Color. In S. Bradley et al. (Eds.), The Scarlet Letter: AN Authoritative Text Backgrounds and Sources Criticism. New York: W.W.Norton and Company.

Male, R. R. (1991). The Tongue of Flame: The Scarlet Letter. Boston: Bedford/st. Martins.

Miller, E. H. (1991). Salem is my dwelling place: A lie of Nathaniel Hawthorne. Iowa: University of Iowa Press.

Rubinstein, A. T. (1988). American: Root and flower. Beijing: Foreign Language Teaching and Research Press.

Schubert, L. (1958). Hawthorne, the Artist. New York: Knopf.

Wendell, B. (1900). A Christmas Masque. New York: C Scribner's Sons.

Whipple, E. P. (1988) A True Artist's Certainty of Touch and Expression Critical Essays on Hawthorne's The Scarlet Letter.

\section{Copyrights}

Copyright for this article is retained by the author(s), with first publication rights granted to the journal.

This is an open-access article distributed under the terms and conditions of the Creative Commons Attribution license (http://creativecommons.org/licenses/by/3.0/). 